DOI: 10.31866/2410-1915.22.2021.235912

UDC 791:[76:655.3.066.24](477)"192/193"

\title{
THE INFLUENCE OF UKRAINIAN FILM POSTERS OF THE 1920s AND 1930s ON CONTEMPORARY GRAPHIC DESIGN
}

\author{
Andrii Budnyk
}

$P h D$ in Art Studies, ORCID:0000-0002-0719-2231, budnik_andriy@ukr.net, Kyiv National University of Culture and Arts, 36, Ye. Konovaltsia St., Kyiv, 01133, Ukraine

\section{For citations:}

Budnyk, A. (2021). The Influence of Ukrainian Film Posters of the 1920s and 1930s on Contemporary Graphic Design. Culture and Arts in the Modern World, 22, 185-198. https://doi.org/10.31866/24101915.22.2021.235912.

The purpose of the article is to analyse the influence of the system of compositional techniques and graphics of the All-Ukrainian Photo Cinema Administration Film Poster School and Ukrainafilm on domestic graphic design. Research methodology. The author has applied historical, art history, and comparative analysis. Scientific novelty. Through the similarity matching in the world and Ukrainian design and the study of the use of design schemes, techniques and tools that are permanently used in graphic design, we reason the influence of the Ukrainian Poster School of the 1920s and 1930s on contemporary graphic design practice. Conclusions. Despite a long break for ideological grounds in the functioning and study of Ukrainian graphic design in the middle of the twentieth century, we record a noticeable influence of the means and techniques of Ukrainian poster art on modern trends. These are general compositional techniques: placing a formatted face or figure as a dominant on the entire plane of the image, designing a composition on the principle of a "playing card", deliberately replacing grounds on the inverted perspective. There are local techniques: concentric circles as a compositional dominant, filling the main character's glasses with visual elements or font content, and rhythmically repeating visual elements or font groups. The identified similarities can be valuable in the young designers training, taking into account the general development of Ukrainian graphics' history and its single branch graphic design. It is also possible to use these schemes, techniques and tools in contemporary design education as a methodological basis for teaching poster design, designing, composition, layout and modelling.

Keywords: poster; Ukraine; All-Ukrainian Photo Cinema Administration; Ukrainafilm; contemporary graphic design; the first third of the twentieth century; design education

\section{Introduction}

The system of compositional techniques and graphic tools, which was developed and implemented in the production film advertising practice of 
All-Ukrainian Photo Cinema Administration, and later "Ukrainfilm" is a valuable heritage of Ukrainian poster graphics of the $20^{\text {th }}$ century. Creative findings made for a decade influenced the domestic graphic design and had and still have analogues in global design. The used schemes have proven to be so viable that they continue to be used in new graphic practice and can be valuable in the young designers training.

Methodology and review of related literature and studies. Over the past decade, increasing attention has been paid to the basics of Ukrainian graphic design and poster, in particular. Research by A. Andreikanich (2013, 2014), A. Budnyk (2017), articles and scientific catalogue by L. Hutnyk (2010, 2018, n. d.), gift editions by Dovzhenko Centre (Silantiev et al., 2015) bring out of oblivion a whole layer of Ukrainian graphic culture, closely connected with another branch of art - cinematography. Sources in the form of catalogues of works by masters of the Ukrainian poster (Verba, 1977) and studies of the Soviet era by the author I. Zolotoverkhova (1983) remain invaluable. O. Lahutenko $(2006,2007,2011)$ made an essential contribution to the poster art review as a branch of Ukrainian graphics. There is increasing attention to the content mentioned above on the Internet and promotion of Ukrainian language posters on Reklamafilm international websites (https://www.reklamafilm.com), Soviet political poster (http:// redavantgarde.com). Admins of these resources are frequently seeking advice on Ukrainian artists' biographies in the structural divisions of the National Union of Artists of Ukraine. There are auctions specialised in posters ("Iz vsekh iskusstv", 2016), large exhibitions, where you can trace the development of the genre you are interested in ("Efemeroidy. XX stolittia", 2016). Western publications on this topic were striking in their high-quality printing, for example, the album ordered by Susan Pack (Pack, 1995), (Strizver, 2017) and the edition called by N. Baburina and made up and edited by M. Anikst (Anikst \& Baburina, 1991). These publications and library collections (Hutnyk, n. d.) are essential components of the empirical research base.

Some articles are published on the ties between constructivism and the latest graphic design - in particular, Russian scientists A. S. Shutova and T. Y. Bystrova (2014) and American researcher Ilene Strizver (2017) wrote about this. But such a comparative analysis is usually based on the practical legacy of Russian designers, which does not show a broad picture. There are individual cases of addressing the Ukrainian heritage in a poster, for example, in the article by L. Hutnyk (2010) about Timofii Liashchuk's film posters. The researcher correctly points out the artistic techniques used in works (Liashchuk is the author of 67 film posters), such as photo collage, dominating a large face, personification (Hutnyk, 2010, p. 583), but does not provide art and historical review of the origins of these artistic and graphic solutions, which were used by artists in film ads at the request of Ukrainian film studios back in the 1920s and 1930s.

Therefore, however making new arrays of information available to the public and attempts to structure it by various indicators (the history of cinema, directing, a famous actor, products of a film studio or its division, a selection of works by a single author) are appreciative, not so often works are published on the system analysis of compositional construction, artistic means and tech- 
niques, as well as their origins and relationships in the domestic graphic culture. Thus, it is worth trying to compare significant periods in the development of Ukrainian graphic design using historical, art and comparative review.

\section{Purpose of the article}

The purpose of the article is to analyse the influence of the system of compositional techniques and graphics of the All-Ukrainian Photo Cinema Administration Film Poster School and Ukrainafilm on domestic graphic design (up today).

\section{Main research material}

In the 1920s and 1930s, the poster, as a genre, overcame the half-century bent for easel painting, moved to the facades of cinemas, poster pillar, city streets, developed its graphic language and a system of graphic means and compositional techniques. In one respect, it was supported by the community and political situation, certain hopes and the demand of society for a renewed life, and on the other, by technological progress in the fields of cinema and book-printing. The short period of the All-Ukrainian Photo Cinema Administration's work (1922-1930) and its hereditary organisation Ukrainafilm (after 1930) became a real breakthrough in cinema and related industries that serve it as graphic design, publishing, and the academic environment. The rapid defeat of the All-Ukrainian Photo-Film Administration (1930) and the subsequent creation of Stalin-type creative unions (1932) changed the productive paradigm to an ideological one. To a small extent, the movement's inertia was retained by All-Ukrainian Photo Cinema Administration's legal successor - Ukrainafilm. Still, this progressiveness did not last long since this organisation was not wholly independent and subordinate to the All-Soviet body "Soyuzkino".

Hiding the achievements of the Ukrainian poster of the 1920s and 1930s, due to the ideological antagonism of the prevailing doctrine of socialist realism, for some time slowed down the development of formal means of the poster, returning them to the past - to the narrative of the easel picture of the $19^{\text {th }}$ century, understandable to the proletarian masses. However, even in the conditions of silence and neglect of the priceless creative heritage, sharp formal decisions sometimes emerged, for example, in T. Liashchuk's posters of the 1970s and 1980s (Hutnyk, 2010; Verba, 1977). According to Soviet-era Ukrainian posterists (Vitalii Shostia, Valerii Viter), they learned about their predecessors' creative achievements more from Western journals than from local art history studies. Partly-clandestine learning of the Ukrainian heritage in the field of film poster and its "filtered" influence on the work of artists of the second half of the $20^{\text {th }}$ century testifies to its value left to us by history.

It is worth considering what tools and techniques were the artistic toolkits in Ukrainian film advertising. It is also necessary to prove that it is precisely because of the primitive use of these techniques that the priority belongs to Ukrainian poster artists (or artists from other republics of the USSR who 
worked on domestic film studios) by the dates of publication. Following, we can list the main compositional techniques of the Ukrainian poster of the 1920s and 1930s, used by modern designers, both domestic and foreign.

Concentric circles. One of the most popular techniques that were used in both linear and tonal versions. This technique is widely used. The first known case is a collage of an unknown author on the theme of the film "Arrest warrant" for the Kino Journal in 1927, where a black-and-white solution was used with circles of the same thickness that keep the levelness of the composition (Fig. 1.1). It bears remembering the brothers Vladimir and Georgii Stenberg with a poster for the 1928 film "The Eleventh Year" (Fig. 1.2) by All-Ukrainian Photo Cinema Administration, which created perspective by bringing the circles closer together when narrowing to the centre, enhanced the dynamics with diagonal stripes with portraits of the main characters, and used contrasting black and yellow colours as eye irritation. After 1930, by order of Ukrainafilm, the artist V. Naumets handed over the baton with a film poster for Sniper (Fig. 1.3), in which he enriched the technique with a black-and-white pattern like chess squares.

In the $21^{\text {st }}$ century, the use of this technique was spotted in Swiss design in the poster by the artist Werner Jeker for the solo exhibition of photographer René Burri (Fig. 1.4), who uses the technique with circles as a space for the coexistence of two circular structures that carry contrasting colours and different content, which consists of a compilation of two photographs by the master of European photography. In the modern Russian documentary film, the Stenberg's Constructivist style continues the poster for the film "Russian Jews Film 2" 2017 (Fig. 1.5) by the embattled TV journalist Leonid Parfyonov. In the design solution, conditional radio waves on a dark blue background carry half-figures of black-and-white characters, emphasising the chronicle character of the film.

This technique can be considered a sign of optical art - Op-Art movement of the second half of the twentieth century, the most prominent representative of which was the Hungarian-French artist Victor Vasarely (1906-1996). The viability of the above technique is confirmed by the presence of a vector template similar to the Stenberg Brothers' design on Depositphotos image stocks in the category "Modern Abstract Circle Background Design Template".

Lenses that reflect a certain plot. A widely-spread technique, which was used in the graphic design of the $20^{\text {th }}$ and the $21^{\text {st }}$ centuries many times, was first used on the Ukrainian-language poster of the Stenberg Brothers for Dziga Vertov's film "The Eleventh Year" (Fig. 2.1). The lenses could reflect both plot events (Fig. 2.1, 2.3, 2.4, 2.6, 2.7, 2.8) and font compositions (Fig. 2.2, 2.5). Cases of using this technique were quite common in the coming years as in The Overthrow poster by J. Kuzkovsky (after 1930) (Fig. 2.2), Things and People poster by L. Voronov (1932) (Fig. 2.3), and in the following decades as in the cover for Northwestern Indiana (1946), the Chambers Brothers psychedelic poster (1967), the poster for the Vinyl TV series (2016, Vinyl, HBO), the cover for the Kyiv University of Culture booklet, Florenz und Seine Maler poster (Fig. 2.4, 2.5, 2.6, 2.7, 2.8).

The principle of the "playing card" composition. It is common in the direct use of an immutable gambling attribute and compositional technique of vertical flipping image. We can see this in the poster by A. Dovzhenko "In the 
clutches of the Soviet regime" in 1926 (Fig. 3.1). The work of the outstanding Master of Ukrainian cinema resembles the main attribute of gambling with a composition, although it does not correspond to the principle of "card game" mirroring. But the portrait orientation of the sheet, its proportions (141.4 and $108 \mathrm{~cm}$ ), the vector of direction of inscriptions from top to bottom, the use of black and red letters, the use of the room on the plane and the decomposition of the capitalist figure in the middle with off-centre vision looks like a large map.

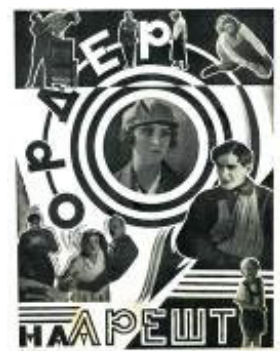

1927

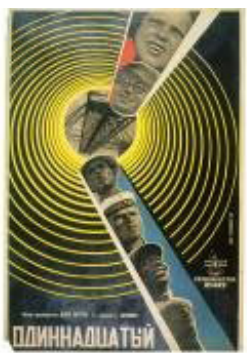

1928

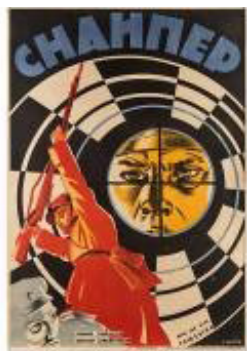

1930

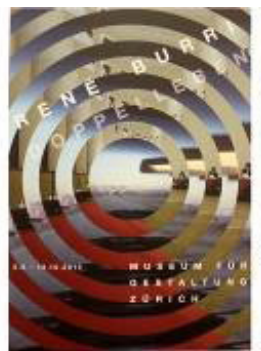

2013

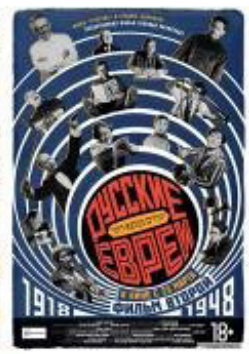

2017

Fig. 1.1.

Fig. 1.2 .

Fig. 1.3.

Fig. 1.5.

Fig. 1.1. Arrest warrant. Unknown author. 1927. Print size. Source: Kino: Ukrainian Cinematography Journal. Kharkiv: All-Ukrainian Photo Cinema Administration 1927. No. 4 (16), Feb. Inner front cover page.

Fig. 1.2. The Eleventh Year. The Stenberg Brothers. 1928. Source: Ukrainian film poster. P. 138.

Fig. 1.3. Film Poster for Sniper. V. Naumets. 1931. Source: https://pikabu.ru/story/ pervaya_mirovaya_ryek_v_sovetskikh_filmakh_i_proizvedeniyakh_5219701.

Fig. 1.4. Solo exhibitions of René Burri. Werner Jeker. 2013. Source: Design Museum. Zurich, Switzerland. 90.5 and $128 \mathrm{~cm}$. Photo by the article's author.

Fig. 1.5. Russian Jews. Film 2. 1918-1946. Unknown author. 2017. Source: https:// www.film.ru/photo/posters/russkie-evrei-film-vtoroy-1918-1948/943786.

There is M. Dlugach's technique that he used for the 1929 "Judge Reitan"/"Double" adventure film directed by F. Lopatynsky by the All-Ukrainian Photo Cinema Administration (Fig. 3.2). The film, which has not been preserved, tells the story of the escape from the prison of a revolutionary sentenced to death due to the physical similarity to a judge. A similar layout principle was adopted by Ibrahim Litinsky in the Guest from Mecca poster (Fig. 3.3), where the graphic solution also successfully illustrated the plot outline with spy things.

In the collection of "card" posters, there are 1926 Hating House posters by L. Kaplan, I. Litinsky's posters for the film "Prosecutor Jordan” (All-Ukrainian Photo Cinema Administration, 1928) and "Salty Boys" ("Ukrainfilm” Odesa Film Factory, 1931), prints printed from the works of unknown artists for the films of Ukrainian production "Michanician and Chancellor" (All-Ukrainian Photo Cinema Administration, 1923) and "The Dike Went"/"Lesya" (1928). Russian 
cinema presented by 1935 poster created by an unknown author for the "Ball and Heart" comedy produced by Mosfilm (Fig. 3.4).

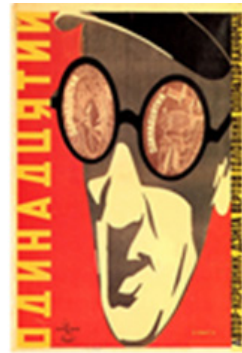

1928

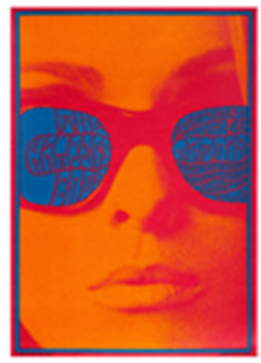

1967

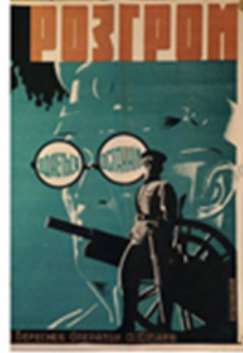

กicng 1930

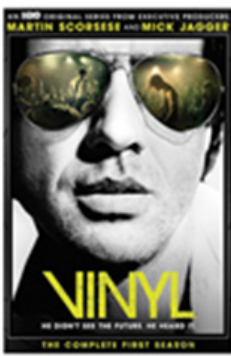

2016

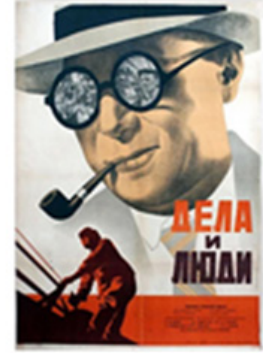

1932

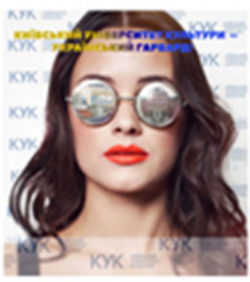

2018

Fig. 2.3.

Fig. 2.7.

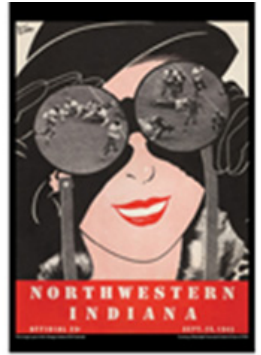

1946

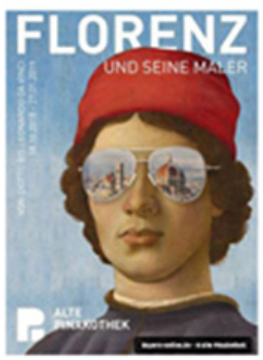

2018

Fig. 2.4.

Fig. 2.8.

Fig. 2.5.

Fig. 2.6.

Fig. 2.1. The Eleventh Year. The Stenberg Brothers. 1928. Source: Vernadsky National Library of Ukraine.

Fig. 2.2. The Overthrow. J. Kuzkovsky. Fragment. After 1930. Source: Litfond Auction House.

Fig. 2.3. Things and people. L. Voronov. 1932. Source: https://www.reklamafilm. com/1931-40?lightbox=dataItem-irox7ud4.

Fig. 2.4. Northwestern Indiana. Brad Pendlton. 1945. Source: Vintage Indiana 2018 Calendar.

Fig. 2.5. Chambers Brothers, March 28-30, 1967 \& April 4-6, 1967 Matrix Club (San Francisco, CA). Victor Moscoso. 1967. Source: http://yep.today/en/january2016/ graphoscope/257/.

Fig. 2.6. Vinyl. HBO. 2016. Source: URL: https://www.amazon.com/VinylComplete-First-Season-Digital/dp/B01BQPZU5C.

Fig. 2.7. Kyiv University of Culture - Ukrainian Harvard. Sofiia Dakhniuk. 2018. Second Year University Student Photo by the article's author.

Fig. 2.8. Florenz und Seine Maler. Alte Pinakothek. 2018. Photo by the article's author.

In recent history, we can find a similar solution in a Ukrainian poster of the late Soviet era, namely, a product by the "Agitplakat" silk-printing workshop at the art plant of the Artists Union of the Ukrainian SSR. The "opposition- 
kinship" principle was used by a member of the Kyiv poster section V. Reshetov in a social anti-bribery poster "The Game Will Be Over!" (Fig. 3.5). In the "19172017” poster, Italian designer Gianni Rossi re-purposes from a poster collection dedicated to the civilising reinterpretation of the $100^{\text {th }}$ anniversary of the October events of the so-called "Revolution of 1917" (Fig. 3.6).

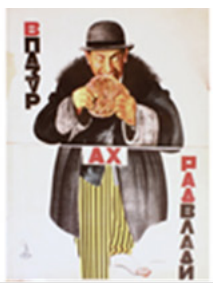

Fig. 3.1.

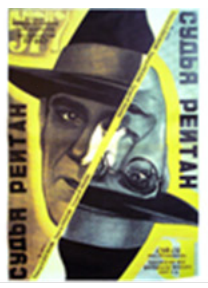

Fig. 3.2.

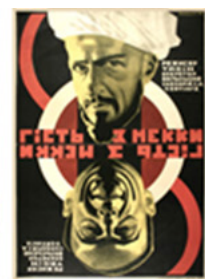

Fig. 3.3.

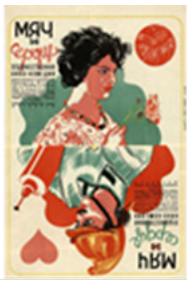

Fig. 3.4.

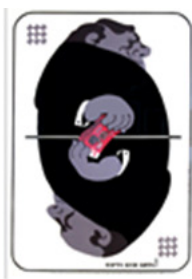

Fig. 3.5.

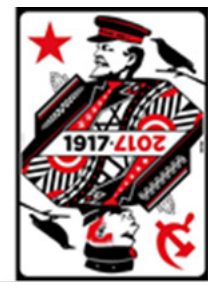

Fig. 3.6.

Fig. 3.1. In the clutches of the Soviet regime. O. Dovzhenko. 1926. All-Ukrainian Photo Cinema Administration. Source: Vernadsky National Library of Ukraine.

Fig. 3.2. Judge Reitan. M. Dlugach. 1929. All-Ukrainian Photo Cinema Administration. Source: Vernadsky National Library of Ukraine.

Fig. 3.3. Guest from Mecca. I. Litinsky. [1930]. 87 and $62.5 \mathrm{~cm}$. Source: Ukrainian film poster.

Fig. 3.4. Ball and Heart. Unknown author. 1935. Source: Moscow: Reklamfilm; Kinofotoizdat, 1935 ( $2^{\text {nd }}$ State Lithography). Colour lithography.

Fig. 3.5. The Game Will Be Over! V. Reshetov. 1988. Source: National Art Museum of Ukraine. Photo by the article's author.

Fig. 3.6. Gianni Rossi. 1917-2017. 2017. Digital printing. Source: 1917-2017 Open Poster Competition. Photo by the article's author.

The rhythmic repetition of graphic elements or font groups. Partially it can be found quite deeply in the history of art, for example, in Sandro Botticelli's "Mystic Nativity" (1500), etc., but usually, this technique was fragmentary and was not dominant. The achievements of constructivism include the strengthening of the role of reception from the secondary to the main, which is crucial on the sheet both in compositional and semantic terms. The photo collage cover by an unknown artist for the $4^{\text {th }}$ issue of Kino Journal in 1928 demonstrates such an "advantage in status" (Fig. 4.1). There is a repetition by the Swiss posterist Werner Jeker (Fig. 4.2). A modern Ukrainian youth poster is presented by the work of a third-year student of the Faculty of Graphic Design and Advertising of the Kyiv National University of Culture and Arts T. Myroniuk “Stanislav Lem” from the Born to the Carpathians-II Poster Collection at the Carpathian Space International Arts Festival, which was held in Ivano-Frankivsk in 2017 (Fig. 4.3).

Deliberate replacement of grounds based on the principle of inverted perspective. Usually, this technique was used together with the opposition of the proportions of the depicted figures or faces. A technique that is too common in advertising for Hollywood films, when you need to focus on the leads, which guarantees the grosses. A smaller figure is placed in the foreground, and a full- 
face image is in the background. It is used, as a rule, in polar opposite tonal or warm-cold solutions, which emphasises the perspective irregularity and illogical ground location. Examples are the journal trailer poster for $1926 \mathrm{~A}$. Bondarovych's "Mykola Dzheria" (Fig. 5.1) and the 2008 poster for the Hollywood blockbuster "Transporter 3" (Fig. 5.2).

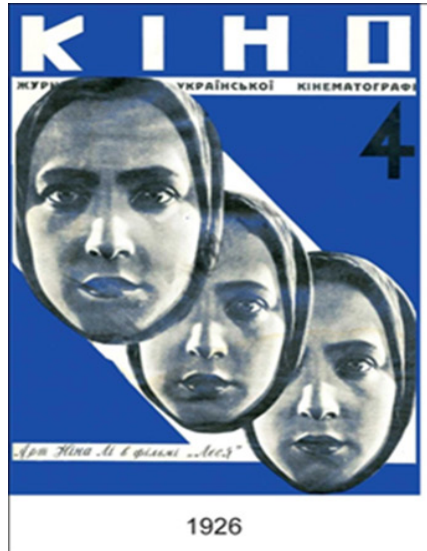

Fig. 4.1.

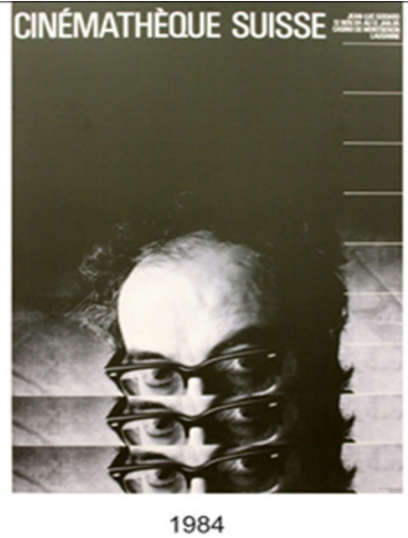

Fig. 4.2.

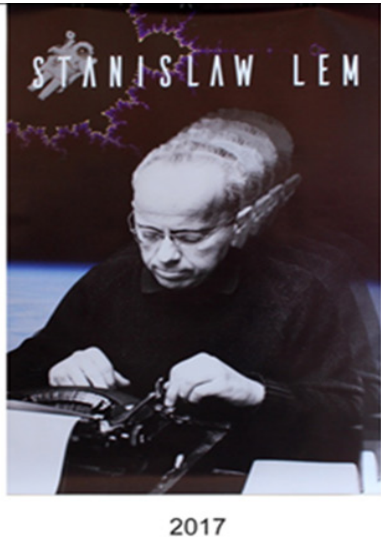

Fig. 4.3.

Fig. 4.1. Cover of the Kino Ukrainian Cinematography Journal. Lesya: [shot fragment]: drama: art. N. Li. Unknown author. 1928. Source: Kino: Ukrainian Cinematography Journal. 1928. № 4 (40), April. front page. https://elib.nlu.org.ua/view. html? \&id=677

Fig. 4.2. Cinémathèque Suisse. A series of screenings of Jean-Luc Godard films. Werner Jeker. 1984. Source: Swiss Film Archive, Lausanne, Switzerland. Photo by the article's author.

Fig. 4.3. Stanislaw Lem. T. Myroniuk. 2017. Source: Born to the Carpathians Poster Collection, the Carpathian Space International Arts Festival. Photo by the article's author.

Local compositional techniques. For example, "Alley of Heroes” with a five-pointed star in the centre in posters of an unknown author of "Ukrazia. 7+2" 1924 (Fig. 6.1) and "Captain America. Civil War" 2016 (Fig. 6.2). If this is not direct plagiarism, then the priority still belongs to the Ukrainian posterist by date. It can be assumed that since the film "Captain America" was produced by Marvel, a publisher of comic books, it is possible that its artists were studying a handdrawn Soviet poster and the copyright period (75 years) that had expired since the premiere of "Ukrazia", and the unidentified authorship of the poster allowed American designers to use the plastic idea of a Ukrainian film poster, the authorship of which can only be attributed to Anatolii Martynov by indirect art study.

Full face image. It is a classic, one can say more, basic principle, which has the roots of construction in the composition of Icon of the Savior "Not Made With Hands". Its use was popular in the 1920s, for both male and female faces (Fig. 7.1, 7.2, 7.3). It laid the foundations for the transition from a realistic 
pictorial image of a human face in the $19^{\text {th }}$ century to a poster graphic stylisation of the next $20^{\text {th }}$ and $21^{\text {st }}$ centuries. The proof is the Barack Obama 2008 campaign poster (Fig. 7.4), quite similar in style, for example, to the film poster for 1928 M. Dlugach's “Cement”.

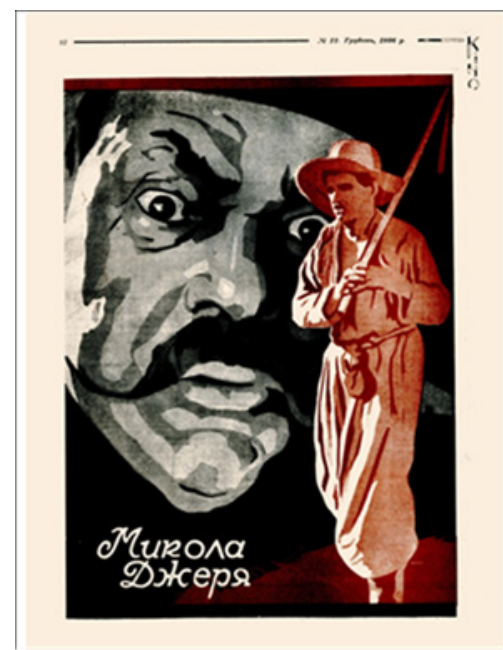

Fig. 5.1.

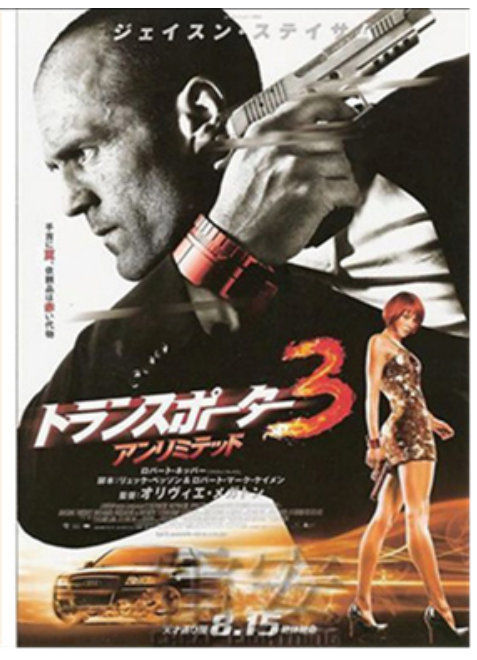

Fig. 5.2.

Fig. 5.1. Mykola Dzheria, film poster reproduction. A. Bondarovych. 1926. Source: Kino: Ukrainian Cinematography Journal. 1926. № 12, Dec. P. 27. https://elib.nlu.org. ua/view.html? \&id=670

Fig. 5.2. Transporter 3. Unknown author. 2008. Source: https://www.filmweb.pl/ film/Transporter+3-2008-466637 / posters.

The current list of techniques and tools that still used in contemporary design practice could have been augmented but the format of the journal article. In short, the general list of techniques as follows: compositional techniques. They are poster where the dominant is one large figure (industrial object / figure layout of thematic elements), poster where the dominant is one large face, main character + figure poster (plot of the film), poster with space segmentation, dynamic diagonal composition, symmetrical compositions (scheme "playing card" as a variety).

Graphic tools. Collage, editing portraits of actors and scenes of the films, using photos as a resource for creating a poster, using geometric shapes, in particular concentric circles, handles/textures on figures (clothes, faces), grounds, silhouettes, fonts as a dominant, fonts as an image, perspective as an analogue of 3D, doubling movements, characters, turns, and dividing in half.

Contrasts. "Negative-positive", including negative shadows from real characters, character lighting - modelling along the border of light and shadow, linear images in contrast with the tone, diverse modelling, deliberate violation of proportions. 


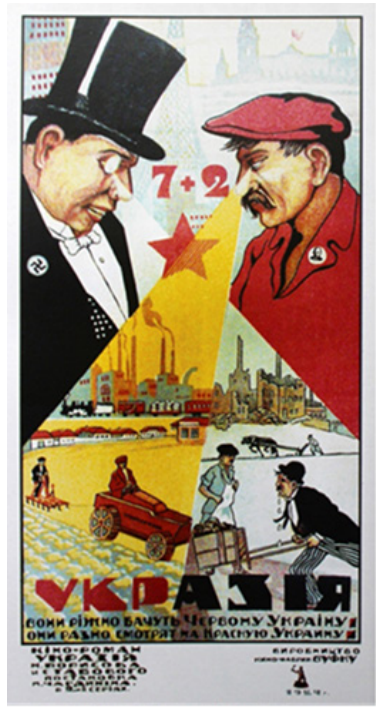

Fig. 6.1.

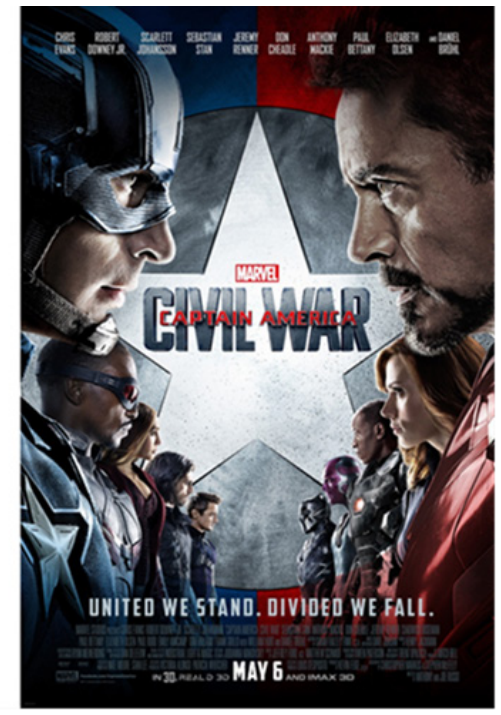

Fig. 6.2.

Fig. 6.1. Ukrazia. 7+2. Unknown author (perhaps A. Martynov). [1924]. Chromolithography. Source: Vernadsky National Library of Ukraine.

Fig. 6.2. Captain America. Civil War. Unknown author. 2016. https://www.imdb. com/title/tt3498820/

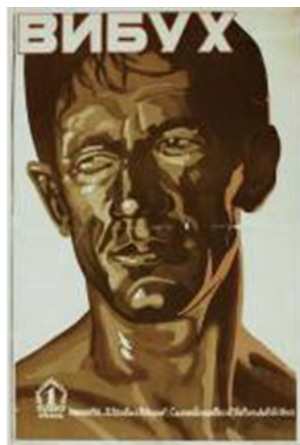

Fig. 7.1

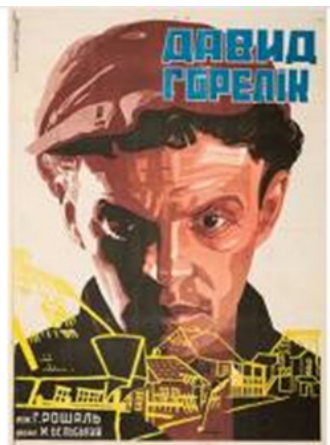

Fig. 7.2

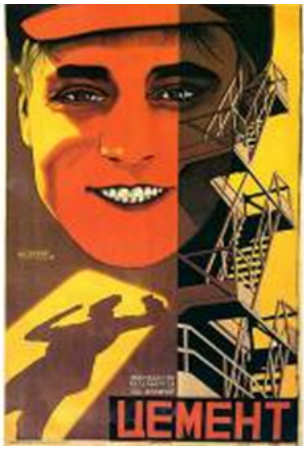

Fig. 7.3

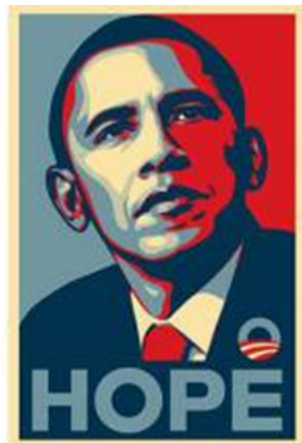

Fig. 7.4

Fig. 7.1. An explosion. Unknown author. [1926]. Chromolithography. Source: Vernadsky National Library of Ukraine.

Fig. 7.2. Davyd Horelyk. J. Kuzkovsky. 1928. Chromolithography. Source: http://www.artnet.com/artists/posters-soviet/movie-poster-david-gorelikLZpM27nOyVlt2rezz76Dfg2

Fig. 7.3. Cement. M. Dlugach. 1928. Chromolithography. Source: Vernadsky National Library of Ukraine.

Fig. 7.4. Barack Obama HOPE Presidential Campaign Poster. Shepard Fairey. 2008. Source: https://www.pinterest.ru/pin/708402216362195287/?1p=true . 


\section{Conclusions}

Thus, for the first time, in this article, the author tracked the precedence of certain compositional schemes' use, design techniques and graphic tools in Ukrainian film posters of the 1920s and 1930s and their further implementation in domestic and world art practice. It is difficult to determine how conscious it was to copy or imitate such techniques by artists of subsequent generations, but the fact remains.

In general, the frequency of using design techniques (both fundamental principles and direct plagiarism) of the Ukrainian poster in the graphic design of the $20^{\text {th }}$ - the $21^{\text {st }}$ centuries indicates the revolutionary nature of their application in the years of All-Ukrainian Photo Cinema Administration. The principal value was the artists' attempts to abandon the picture-painting paradigm of easel painting and develop a new toolkit that could not be used in oil painting intended for indoor chamber exhibiting. Recent times required a new artistic language, less narrative and more dynamic, and it was invented. The identified similarities can be valuable in the young designers training following the general development of the history of Ukrainian graphics and its separate branch graphic design. The value lies in the use of schemes, techniques and tools in contemporary design education as a methodological basis for teaching poster design, designing, composition, layout and modelling.

\section{References}

Andreikanich, A. I. (2013). Maister ukrainskoho kinoplakata - Ibrahim Litynskyi [Ibrahim Litinsky, The Master of the Ukrainian Film Poster]. Bulletin of Kharkiv State Academy of Design and Arts, 2, 113-116 [in Ukrainian].

Andreikanich, A. I. (2014). Ukrainski maistry kinoplakata pershoi tretyny XX stolittia: Albom [Ukrainian Masters of Film Posters of the First Third of the $20^{\text {th }}$ Century: Album]. Dovbush [in Ukrainian].

Anikst, M., \& Baburina, N. (Eds.). (1991). Soviet Commercial Design of the Twenties. Abbeville Press [in English].

Budnyk, A. V. (2017). Zasoby i pryiomy dyzainu ukrainskoho vydovyshchnoho plakatu pershoi tretyny XX stolittia [Means and Techniques of Design of the Ukrainian Poster of the First Third of the $20^{\text {th }}$ Century] [PhD Dissertation]. Kyiv National University of Culture and Arts [in Ukrainian].

Efemeroidy. XX stolittia u plakati [Ephemeroids. The 20 $0^{\text {th }}$ Century in the Poster]. (2016, October 20 - November 27). Mystetskyi Arsenal. https://artarsenal.in.ua/vystavka/ efemeroyidy-hh-stolittya-u-plakati/ [in Ukrainian]

Hutnyk, L. M. (2010). Kinoplakat u tvorchosti ukrainskoho khudozhnyka T. A. Liashchuka (za materialamy zibrannia NBUV) [Film Poster in the Works of Ukrainian Artist T. A. Liashchuk (Based on the Materials of the Vernadsky National Library of Ukraine Collection)]. Academic Papers of The Vernadsky National Library of Ukraine, 28, 575-587 [in Ukrainian].

Hutnyk, L. M. (2018). Ukrainskyi kinoplakat 1947-1994 rokiv z fondiv Natsionalnoi biblioteky Ukrainy imeni V. I. Vernadskoho: naukovyi kataloh [Ukrainian Film Poster 
of 1947-1994 from the Funds of the Vernadsky National Library of Ukraine: Scientific Catalogue]. Akademperiodyka [in Ukrainian].

Hutnyk, L. M. (n.d.). Kolektsiia ukrainskoho radianskoho kinoplakata 1920-30-kh rokiv [Collection of Ukrainian Soviet Film Posters of the 1920s and 1930s]. http://www. nbuv.gov.ua/node/371 [in Ukrainian].

"Iz vsekh iskusstv vazhneishim dlya nas yavlyaetsya kino...": kinoplakaty XX veka. Auktsion №8 ["Of All the Arts, Cinema is the Most Important For Us ...": Film Posters of the $20^{\text {th }}$ Century. Auction №8]. (2016, February 25). Litfond. https://www.litfund.ru/ auction/8/ [in Russian].

Lahutenko, O. (2006). Ukrainska hrafika pershoi tretyny XX stolittia [Ukrainian Graphics of the First Third of the $20^{\text {th }}$ Century]. Hrani-T [in Ukrainian].

Lahutenko, O. (2007). Graphein. Hrafiky: narysy z istorii ukrainskoi hrafiky XX stolittia [Graphein. Graphics: Essays on the History of Ukrainian Graphics of the $20^{\text {th }}$ Century]. Hrani-T [in Ukrainian].

Lahutenko, O. (2011). Ukrainska hrafika XX stolittia [Ukrainian Graphics of the 20 Century]. Hrani-T [in Ukrainian].

Pack, S. (1995). Film Posters of the Russian Avant-Garde. Taschen [in English].

Shutova, A. S., \& Bystrova, T. Yu. (2014, December 4-5). Ispol'zovanie priemov konstruktivizma $\mathrm{v}$ sovremennom graficheskom dizaine [Receiving Use Constructivism in Modern Graphic Design]. In Ural industrial'nyi. Bakuninskie chteniya: Industrial'naya model' Urala v XVIII-XIX vekakh [The Ural is Industrial. Bakunin Readings: The Industrial Model of the Urals in the $18^{\text {th }}-19^{\text {th }}$ Centuries], XII All-Russian Scientific Conference (Vol. 2, pp. 346-349), Ekaterinburg [in Russian].

Silantiev, S., Horbachov, D., \& Hoseiko, L. (2015). Ukrainskyi kinoplakat 1920-kh rokiv. VUFKU [Ukrainian Film Poster of the 1920s. VUFKU]. Natsionalnyi Tsentr Oleksandra Dovzhenka [in Ukrainian].

Strizver, I. (2017, September 27). Russian Constructivism and Graphic Design. CreativePro. https://creativepro.com/russian-constructivism-and-graphic-design/ [in English].

Verba, V. M. (Ed.). (1977). Tymofii Liashchuk: kataloh personalnoi vystavky [Tymofii Liashchuk: Personal Exhibition Catalogue]. Kyiv [in Ukrainian].

Zolotoverkhova, I. I. (1983). Ukrainskyi radianskyi kinoplakat 20-30-kh rokiv [Ukrainian Soviet Film Poster of the 20s and 30s]. Naukova dumka [in Ukrainian]. 


\section{ВПЛИВ УКРАЇНСЬКОГО КІНОПЛАКАТА 1920-1930-х рp. НА СУЧАСНИЙ ГРАФІЧНИЙ ДИЗАЙН}

\section{Будник Андрій Вікторович}

Кандидат мистецтвознавства, ORCID:0000-0002-0719-2231, budnik_andriy@ukr.net, Київський національний університет культури і мистецтв, Київ, Україна

Мета дослідження - проаналізувати вплив системи композиційних прийомів і графічних засобів художньої мови кіноплакатної школи ВУФКУ і «Українафільму» на вітчизняний графічний дизайн. Методи дослідження. Історичний, мистецтвознавчий і порівняльний аналіз. Наукова новизна. Через пошук відповідників у світовому і українському дизайні та аналіз використання дизайнерських схем, прийомів і засобів, що перманентно застосовуються у творах графічного дизайну, обгрунтовується вплив української плакатної школи 1920-1930-х рр. на сучасну графічно-дизайнерську практику. Висновки. Незважаючи на тривалу перерву 3 ідеологічних причин у функціонуванні і вивченні українського графічного дизайну в середині XX століття, фіксуємо помітний вплив засобів і прийомів українського плакатного мистецтва на сучасні тренди. Це загальнокомпозиційні прийоми: розміщення у якості домінанти на всю площину відбитку форматних обличчя або постаті, побудова композиції за принципом «гральної карти», навмисна заміна планів за принципом зворотної перспективи. Також локальні прийоми: використання концентричних кіл як композиційної домінанти, заповнення окулярів головного героя ілюстративним або шрифтовим контентом, ритмічне повторення зображувальних елементів або шрифтових груп. Виявлені паралелі можуть бути корисними у навчальному процесі підготовки молодих дизайнерів з огляду на загальний розвиток історії вітчизняної графіки і окремої її ланки - графічного дизайну. Також не виключена особлива корисність у використанні означених схем, прийомів і засобів у сучасній дизайнерській освіті як методологічних засад викладання дисциплін із плаката, дизайн-проєктування, композиції, макетування і моделювання.

Ключові слова: плакат; Україна; ВУФКУ; Українафільм; сучасний графічний дизайн; перша третина XX ст.; дизайнерська освіта 


\section{ВЛИЯНИЕ УКРАИНСКОГО КИНОПЛАКАТА 1920-1930-х гГ. НА СОВРЕМЕННЫЙ ГРАФИЧЕСКИЙ ДИЗАЙН}

\section{Будник Андрей Викторович}

Кандидат искусствоведения, ORCID:0000-0002-0719-2231,budnik_andriy@ukr.net, Киевский национальный университет культуры и искусств, Киев, Украина

Цель исследования - проанализировать влияние системы композиционных приемов и графических средств художественного языка киноплакатной школы ВУФКУ и «Украинафильма» на отечественный графический дизайн. Методы исследования. Исторический, искусствоведческий и сравнительный анализ. Научная новизна. Путем поиска соответствий в мировом и украинском дизайне и анализа использования дизайнерских схем, приемов и средств, которые перманентно применяются в произведениях графического дизайна, доказывается влияние достижений украинской плакатной школы 1920-1930-х гг. на современную графическо-дизайнерскую практику. Выводы. Несмотря на длительный перерыв в функционировании и изучении украинского графического дизайна по идеологическим причинам, в середине XX века фиксируем заметное влияние средств и приемов украинского плакатного искусства на современные тренды. Это общекомпозиционные приемы: размещение в качестве доминанты на всю плоскость отпечатка большого лица или большой фигуры, построение композиции по принципу «игральной карты», нарочитая замена планов по принципу обратной перспективы. Используются также локальные приемы концентрические круги в качестве композиционной доминанты, заполнение очков главного героя иллюстративным или шрифтовым содержанием, ритмичное повторение изобразительных элементов или шрифтовых групп. Обнаруженные параллели могут быть полезными в учебном процессе подготовки молодых дизайнеров, учитывая общее развитие истории отечественной графики и ее отдельного звена - графического дизайна. Отмечена особая польза в использовании указанных схем, приемов и средств в современном дизайнерском образовании как методологических основ преподавания дисциплин по плакату, дизайн-проектированию, композиции, макетированию и моделированию.

Ключевые слова: плакат; Украина; ВУФКУ; Украинафильм; современный графический дизайн; первая треть XX в.; дизайнерское образование 